\title{
A Study of Participation Motivation, Experience and Satisfaction in Camping Tourists
}

\author{
Ching-Hui Lin, Ying-Wan Chuang \\ Physical Education Office, Yuan Ze University, Chinese Taipei \\ Email: lin-ching-hui@saturn.yzu.edu.tw
}

How to cite this paper: Lin, C.-H. and Chuang, Y.-W. (2021) A Study of Participation Motivation, Experience and Satisfaction in Camping Tourists. Open Journal of Applied Sciences, 11, 190-201. https://doi.org/10.4236/ojapps.2021.112013

Received: December 25, 2020

Accepted: February 23, 2021

Published: February 26, 2021

Copyright $\odot 2021$ by author(s) and Scientific Research Publishing Inc. This work is licensed under the Creative Commons Attribution International License (CC BY 4.0).

http://creativecommons.org/licenses/by/4.0/

(c) (i) Open Access

\begin{abstract}
In recent years, camping is popular in Taiwan, but the research on campers' participation behavior is still insufficient. The purpose of this research is to analyze the structural relationship between camping tourists' motivation, experience, and satisfaction. The survey was conducted in a convenient sampling method, and a total of 464 valid questionnaires were collected. After descriptive statistics and partial least squares (PLS) statistics analysis, the results show that the higher the motivation of camping tourists, the more positive their experience and the higher their satisfaction. In addition, this research also confirms that experience has a mediating effect on motivation and satisfaction in terms of academic theory.
\end{abstract}

\section{Keywords}

Participation Motivation, Experience, Satisfaction, Camping Tourism

\section{Introduction}

In recent years, the population participating in camping during holidays has grown rapidly and has become one of the main projects for people to participate in outdoor recreational activities. Camping is an outdoor recreational activity, usually, campers bring tents and picnic tools, leave the city to camp in the wild, spend one or more nights. Camping is usually associated with other activities, such as hiking, $\mathrm{B} \& \mathrm{Q}$, fishing or swimming. Camping tourism represents a growing part of the overall tourism industry. Despite this fact, this form of tourism has so far been rather neglected by tourism and hospitality research [1]. With the growing interest in camping tourism, the demand for high-quality services and infrastructure is also increasing. Therefore, operators of camping activities should meet the various needs and expectations of the growing tourist 
public. It is very important to understand the motivation of camping tourists to participate [2], which is similar to the motivation of consumption. In particular, the motivation-satisfaction relationship has always been a popular research interest of many scholars, because satisfaction has been shown to have a positive impact on tourists' post-purchase behavior, such as recommendation [3] and revisit intention [4]. Therefore, for sellers of camping activity supplies and camping site operators, understanding the experience of camping participants is an important part. Because camping participants will definitely leave special feelings and experiences after each recreational activity. If this experience is positive, it means that the camping participants are satisfied with the activities, the people and the environment they have encountered. Based on the above background analysis, this study intends to select camping participants' motivation for participation, experience, and satisfaction, and examine their internal relationships from a structural perspective, establishes conceptual models and assumptions based on the literature review. It is very important to understand the motivation of camping tourists, because this is their consumption motivation [2].

Based on the above background analysis, this study analyzes the internal relationship of campers' participation motivation, leisure experience and satisfaction from the perspective of structure. And according to the relevant literature, this paper establishes a conceptual model and hypothesis, and uses empirical analysis to verify it. It is hoped that this study can be a reference for campers and product sellers in practical marketing.

\section{Literature Review}

\subsection{Participation Motivation}

Munn, Fernald, and Fernal [5] define motivation as: an individual's internal movement, such as interest and attitude, which can influence the behavior and cause the change to be. Drive can induce individuals to engage in specific behaviors. They have the instinct, impulse, and emotion of the individual to move. This movement is from the inside, and the strong performance is affected by the environment [6]. According to this application, people's motivation to perform an activity depends on people's expectation that they can perform the activity and obtain the desired results, as well as the personal value of all the results related to the activity [7]. Motivation can be regarded as an internal force, which affects individual behavior and can help them obtain certain desired experiences or results [8] [9] [10]. Driver's [8] research identified 21 unique areas of expected experience that are usually pursued by people who participate in outdoor recreation. They developed the REP scale to analyze recreational participation preferences and experiences. Driver [8] found that there are significant differences in motivations for different types of outdoor activities, and each type of activity occurs in a different environment. Since then, a large number of studies have used the REP scale and demonstrated its reliability in measuring personal entertainment preferences [11]. Crandall [10] found that people's motivation to par- 
ticipate in leisure can be divided into: enjoy nature and escape civilization; escape daily routines and duties; exercise; creativity; physical and mental release; social interaction; contact with new people; contact with the opposite sex; Family communication; gain status; social rights; altruism; seek stimulation; self-realization; accomplishment, challenge, competition; pass the time, avoid boredom; aestheticism. Because camping activities are outdoor-based activities, according to research by Whiting, et al. [12] participants in outdoor recreational activities can be divided into four broad motivation categories: social interaction, physical health and fitness, relaxation and recovery, and natural interaction. Participants believe that all motivation categories are important; however, the motivation for social interaction is the most common among all groups. According to research, the main motivations of participating campers are "stay outdoors and enjoy nature", "breath fresh air", "promote family harmony", "meet with others" and "pay less for accommodation" [13]. In particular, some scholars believe that "escape from daily life and enjoy nature" is an influential motivation for participating in camping [14] [15].

\subsection{Experience}

Although motivation generates important information about why people engage in camping activities, it does not necessarily indicate why such activities occur. Therefore, research on determining preferences for specific places and their connections with various motivations and experiences has become increasingly important [12]. Schmitt [16] put forward the concept of experiential marketing. He believes that with senses, emotions, thinking, actions and related experience activities, consumers can obtain unique and unforgettable experiences. Today's rapid advancement in information technology has increased the symmetry of information between consumers and brands. In addition to giving consumers more choices, they also increase the content of many information searches to make consumers more aware of brands. Schmitt [17] believes that the general theoretical definition of marketing usually focuses on product advantages and characteristics, and provides technical recommendations and introductions to consumers, sometimes supplemented by price concessions to attract consumers to purchase; and experience Marketing pays more attention to purchase elements at the emotional and spiritual level, such as context and user experience, which allow consumers to directly feel the characteristics of the product, thereby attracting purchases. Therefore, the characteristics of experiential marketing can be found, including experiential marketing focusing on how to provide the value of consumer perception, emotion, cognition, behavior, and relationship, as well as the perception that consumers are perceptual, and the decision-making process is often influenced by emotion [18]. Garst, et al. [19] found that camping experience and outdoor forest experience have common characteristics, such as connection with nature, social interaction, escapism and self-renewal. The positive experience results of holiday camping have been specifically discovered in previous studies. For example, vacation camping provides opportunities for personal 
and social development, such as confidence, self-esteem, teamwork skills and increased social capital [20], as well as opportunities for building relationships [21].

\subsection{Satisfaction}

Satisfaction is mainly derived from consumer behavior. According to Kolter [22], satisfaction refers to the difference function between perceived function and expectation. Therefore, customer satisfaction comes from the perception of product features or results. As well as the personal expectations of the product, the degree of pleasure or disappointment formed after the comparison of the two, if the functional characteristics are far less than expected, the customer will feel dissatisfied, otherwise satisfied. In the conceptualization of satisfaction, Tian-Cole and Cromption [23] pointed out two methods: one is based on requirements, the other is based on evaluation. According to the definition of demand, there is a close relationship between motivation and satisfaction. Satisfaction "comes from the satisfaction of corresponding needs or motives". According to the expectancy disconfirmation theory (EDT) proposed by Oliver [24], it is believed that the customer has formed the expected expectation before consumption. If the expectation and the perception after the experience produce inconsistent results, it is called disconfirmation. In other words, when the actual performance is higher than the previous expectations, it will form a positive failure, which will lead to a higher degree of satisfaction. Negative failure will lead to dissatisfaction, and dissatisfaction is the main factor causing customer complaints. In the recreational environment, the expected price theory shows that people participate in outdoor recreational activities to satisfy their preferences, motivations or expected experiences [25] [26]. Therefore, in this theoretical viewpoint, the distance between expectation and the perceived reality of experience is defined as recreation satisfaction [27]. In this research context, recreational satisfaction operates as the consistency between the desired experience and the perception of experience related to the appearance of the entertainment venue [28].

\section{Methodlogy}

\subsection{Hypothesis}

From the concept of motivation and satisfaction, we can find that demand, expectation and satisfaction are closely related [29]. Although satisfaction and motivation are distinct structures, there is an indirect relationship between them [30]. Many tourism and tourism literature researchers adopt a demand-based approach, taking motivation variables as direct antecedent variables of tourist satisfaction [31] [32]. Prebensen, Woo, Chen, and Uysal [33], for example, found that not only does motivation affect tourists' experience, it relates to their level of involvement or engagement. As Battour, Ismail, Battor, and Awais [34] research found that the different dimensions of motivations were found to positively influence satisfaction. 
$\mathrm{H} 1$ : the higher the participation motivation of camping tourists, the leisure experience is higher and positive.

$\mathrm{H} 2$ : the higher the participation motivation of camping tourists, the satisfaction is higher.

$\mathrm{H} 3$ : the higher the leisure experience and positive of camping tourists, the satisfaction is higher. As Battour, Ismail, Battor, and Awais [34] research found that the different dimensions of motivations were found to positively influence satisfaction. According to the above analysis, this study puts forward the following three hypotheses, and the influence relationship between models is shown in Figure 1.

\subsection{Subjects and Sampling}

In this study, people who participated in camping activities were taken as subjects. The survey was conducted in a legal outdoor camping area in Putian City, and convenient sampling methods were used. Due to the inability to estimate the number of samples correctly, a total of 500 questionnaires were give participants fill out in this study, and 464 valid questionnaires were retrieved. The effective questionnaire rate was $92.8 \%$.

\subsection{Questionnaire}

This research questionnaire is divided into four parts. The first part is the camping participation motivation scale, mainly to understand the reasons why camping participants participate in camping activities. This part of the scale has 20 items and is divided into 4 factors, namely stress release, healthy physical fitness, interpersonal interaction and ability achievement. This part of the scale mainly refers to the scale of leisure participation motivation [8] [10] and the research of camping participation motivation [13] [14] [15]. The second part is the experience scale, mainly to understand the interaction and feelings between individuals and the environment during camping participants' participation in activities. This part of the scale has 24 items and is divided into 5 factors, namely: think, feel, sense, act, and relate experience. This part of the scale mainly refers to Schmitt [16] [17] pointed out that there are five aspects of consumer experience and the related leisure experience [18] [19] [20]. The third part is the satisfaction scale. There are 6 questions in this part of the scale. The main

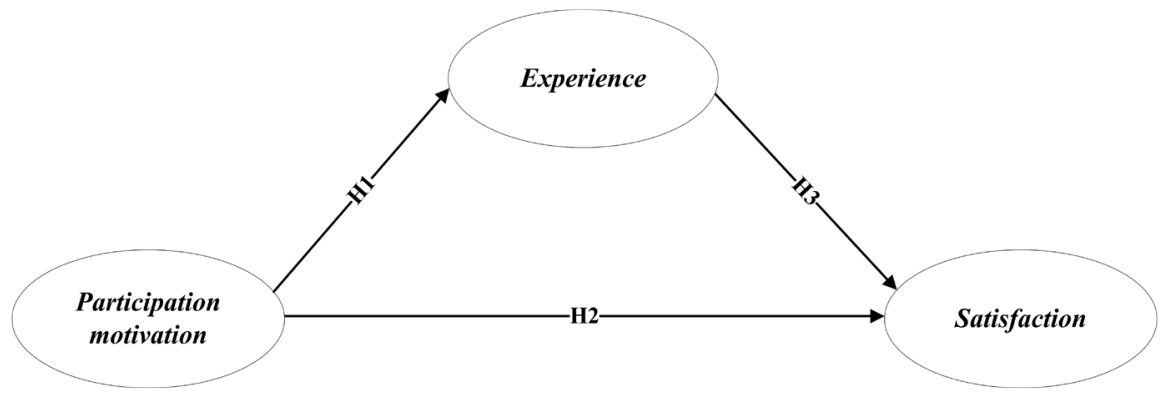

Figure 1. Hypothesis model. 
purpose of this part is to understand the psychological, interpersonal, and environmental satisfaction of camping participants. This part of the scale is mainly compiled with reference to leisure satisfaction and related camping research [26] [27] [28]. The above three quantities are measured using the Likert five-point scale, ranging from "strongly agree" (5 points), "agree" (4 points), "normal" (3 points), "disagree" ( 2 points), to "very agree" (1 points), "disagree" (1 point).The fourth part is camping participants, their demographic characteristics, including: gender, age, education level, marital status, monthly income, and occupation.

\subsection{Statistical Methods}

The statistical analysis steps of the valid questionnaires collected in this study are as follows: 1) Use SPSS for Windows 23.0 to describe the frequency distribution and percentage of statistics, and analyze the distribution of demographic variables of camping participants. 2) Use Warp PLS 7.0 statistical software to analyze the participation motivation, experience, and the reliability and validity of the satisfaction scale of camping participants with the partial least squares (PLS) statistical method, as well as the influence relationship between three latent variables. This research mainly adopts PLS. For the causal model analysis between latent variables, it is better than the general linear structural relationship model. It is suitable for exploratory research. It can not only accept the aspect of a single item, but also is not affected by the variable allocation pattern and sample. It has good predictive and explanatory capabilities [35] [36]. PLS-SEM can simultaneously detect the path (structure model) and factors (measurement model) in one model. In addition, PLS-SEM combines factor analysis and the minimum hypothesis close to regression analysis, and the obtained $\mathrm{R}^{2}$ value represents the degree to which the independent variable can explain the dependent variable.

\section{Results}

\subsection{Respondents Profile}

Among the 464 valid subjects in this study, 191 (41.2\%) were males and 273 (58.8\%) were females. In terms of marital status, there are 186 unmarried (40.1\%) and 278 married (59.9\%).

The age of the subjects was $106(22.9 \%)$ aged $20-30,275$ (59.5\%) aged $21-30$, $50(10.8 \%)$ aged $31-40$, and 23 aged $41-50(5 \%), 8$ persons (1.7\%) are over 50 years old. In terms of education level, there are 25 (5.4\%) in junior high school (including below), 96 (20.9\%) in high school level, 45 (9.8\%) in junior college degree, $277(60.2 \%)$ in university degree, and graduate degree are 17 people (3.7\%). In terms of occupation, students are the highest with 160 (34.5\%), followed by 107 (23.1\%) in business services, and at least $10(2.2 \%)$ in agriculture and fishery.

In terms of personal monthly income, there are 173 people $(37.7 \%)$ with a monthly income below US\$1000, 93 people (20.3\%) with a monthly income of US\$ 1001 - 1500, and some with a monthly income of US\$ 1501 - 200031 people 
(6.8\%), 10 people (2.2\%) above US\$ 2000, 152 people (33.1\%) have no income (students).

\subsection{Analysis of the Reliability and Validity of Scales}

The results of the analysis from Table 1 show that the reliability of the composition and Cronbach's $\alpha$ value of each observed latent variable of each scale in this study are higher than 0.80 , so it has high reliability. In terms of validity, the average amount of variation extracted from the latent variables of each scale is higher than 0.60 , which shows that this scale has a high degree of convergent validity.

\subsection{Analysis of Discriminant Validity}

The results in Table 2 show that the square root of AVE of all potential variables is between 0.81 and 1 , and the AVE of each potential variable is greater than the correlation coefficient in the same column, indicating that the measurement models of each scale have good discriminant validity.

\subsection{Analysis of Structure Model}

In Figure 2, the path coefficient is standardized expression coefficients ( $\beta$ value). The analysis results show that participation motivation has a positive effect on experience $(\beta=0.82, \mathrm{p}<0.01)$; participation motivation $(\beta=0.16, \mathrm{p}<0.01)$ and serious leisure $(\beta=0.70, \mathrm{p}<0.01)$ also have a positive effect on satisfaction. From

Table 1. Analysis of the reliability and validity of scales.

\begin{tabular}{cccc}
\hline Latent variables & CR & Cronbach's $\boldsymbol{\alpha}$ & AVE \\
\hline $\begin{array}{c}\text { Participation motivation } \\
\text { Social interaction }\end{array}$ & 0.93 & 0.90 & 0.67 \\
Health physical fitness & 0.91 & 0.97 & 0.66 \\
Pressure release & 0.88 & 0.82 & 0.65 \\
Ability achievement & 0.89 & 0.83 & 0.67 \\
Experience & & & 0.69 \\
Think & & 0.89 & 0.69 \\
Feel & 0.92 & 0.89 & 0.68 \\
Sense & 0.92 & 0.84 & 0.73 \\
Act & 0.90 & 0.88 & 0.75 \\
Relate & 0.92 & 0.83 & 0.62 \\
Satisfaction & 0.90 & 0.87 & \\
\hline
\end{tabular}

Table 2. Analysis of discriminant validity.

\begin{tabular}{cccc}
\hline Latent variables & Participation motivation & Leisure experience & Satisfaction \\
\hline Participation motivation & 0.812 & 0.820 & 0.715 \\
Experience & 0.820 & 0.891 & 0.812 \\
Satisfaction & 0.715 & 0.812 & 10.000 \\
\hline
\end{tabular}




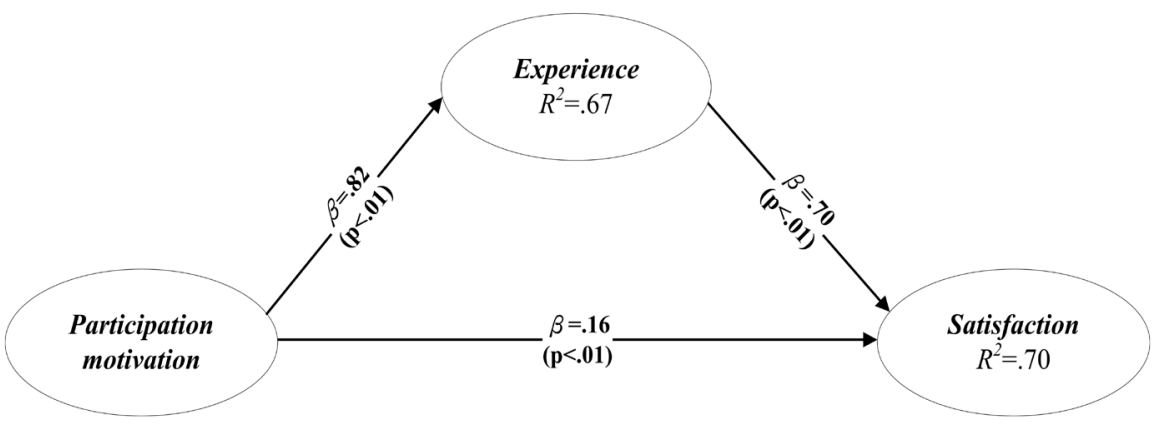

Figure 2. Structure model.

the aforementioned structural relationship, because camping participation motivation has a positive effect on experience and satisfaction, leisure experience also plays a part of intermediary role in the structural model. In addition, from the results of the relationship between the variables in Figure 2, that the explanatory power of participation motivation to experience is $67 \%$, and that to satisfaction through experience is $70 \%$.

\section{Discussion}

The results of the analysis found that tourists' motivation to participate in camping activities has a positive influence on the participation experience, and therefore supports Hypothesis 1.

It shows that the main purpose of camping tourists participating in camping activities is to achieve "physical and mental release", "healthy physical fitness", "learning new knowledge", "interpersonal interaction" and "self-challenge". The above results are consistent with the results of related studies on outdoor recreation and camping motivation [11] [12] [13] [14] [15]. It also means that when tourists are motivated to participate, their thinking, emotions, senses, actions, and related experiences are not only higher but also more positive during the camping process.

Then the results of the analysis found that tourists' motivation to participate in camping activities has a positive impact on their satisfaction with participation, and therefore supports Hypothesis 2. This also shows that when tourists engage in activities, the actual situation can meet their expectations, so their satisfaction is very high. The above results also support related research findings [29] [30]. However, from the perspective of explanatory power, although motivation has a direct impact on satisfaction, the impact through experience is higher.

The results of the analysis found that tourists' experience in camping activities has a positive impact on their satisfaction with participation, and therefore supports Hypothesis 3. Therefore, from the above results, some past recreational studies only emphasized the importance of motivation and satisfaction, but ignored the experience of participating in the activity site [31] [32]. From the above-mentioned research findings, participating in camping activities, experience plays an important role [30]. 
This study found that camping participation motivation and experience have a direct impact on satisfaction, but recreational participation motivation through experience has a more significant impact on satisfaction. In other words, analyzed by the EDT theory [24], people have a high degree of motivation to participate. Need to go through the experience of participation. If the experience is positive, their satisfaction will be higher. Otherwise, dissatisfaction will arise.

\section{Conclusions and Suggestions}

\subsection{Conclusions}

Therefore, from the above discussion, this study has the following three conclusions: 1) When camping tourists are motivated to participate, and the activity can meet their expectations, the experience is more positive and the satisfaction is higher. 2) Tourists participating in camping activities, the experience in the process has a direct effect on their satisfaction. 3) The experience of tourists participating in camping activities plays an intermediary role between participation motivation and satisfaction.

\subsection{Suggestions}

\subsubsection{Suggestions to Government Sectors}

At present, camping activities have gradually become a trend in many countries. First of all, from the perspective of the motivation of tourists to participate in this research, contact with nature, social interaction, psychological release and self-growth are the reasons for their participation in activities. Therefore, in the promotion strategy of government sectors, special festivals are used to promote activities to attract and encourage people to participate, and through activities to promote and inform the people of the benefits of participating in camping activities. In addition, it is necessary for government departments to plan and develop camping areas by enterprises because it is very important for families to choose proper outdoor recreational activities during weekends and holidays, which can help improve the quality of life of the people.

\subsubsection{Recommendations for Camping Operators}

For business operators, in addition to assisting and sponsoring leisure activities organized by the government, the most important thing is to persuade people to understand the benefits of camping activities so that they can start participating in activities. In addition, the industry should organize a camping membership club, so that members can learn about various camping information, so that the industry can have long-term benefits. In addition, for the operators of the camping area, the maintenance of the natural environment, the provision of auxiliary camping equipment, and good service quality can provide tourists with a good experience and satisfaction. 


\subsubsection{Suggestions for Future Researchers}

This research is aimed at camping tourists, but there are many types of outdoor recreational activities. Future researchers can investigate different activities and compare them with this research to understand whether other activities have different results. In addition, in the research area, camping tourists from different areas can also be surveyed or other outdoor recreational activities, to understand the relationship between motivation, experience and satisfaction. In addition, in terms of research variables, since there are many variables in outdoor recreation participation behavior, there may be mediating or interfering effects on the satisfaction of participants. It is recommended that future researchers can add relevant variables for discussion and analysis.

\section{Conflicts of Interest}

The authors declare no conflicts of interest regarding the publication of this paper.

\section{References}

[1] Mikulić, J., Prebežac, D., Šerić, M. and Kreŝić, D. (2017) Campsite Choice and the Camping Tourism Experience: Investigating Decisive Campsite Attributes Using Relevance-Determinance Analysis. Tourism Management, 59, 226-233. https://doi.org/10.1016/j.tourman.2016.07.020

[2] MacLeod, N. (2017) Camping Tourism. In: Lowry, L.L., Ed., The SAGE International Encyclopedia of Travel and Tourism, SAGE Publications, Inc., London, 1124-1229.

[3] Prebensen, N., Skallerud, K. and Chen, J.S. (2010) Tourist Motivation with Sun and Sand Destinations: Satisfaction and the Wom-Effect. Journal of Travel \& Tourism Marketing, 27, 858-873. https://doi.org/10.1080/10548408.2010.527253

[4] Alegre, J. and Cladera, M. (2009) Analysing the Effect of Satisfaction and Previous Visits on Tourist Intentions to Return. European Journal of Marketing, 43, 670-685. https://doi.org/10.1108/03090560910946990

[5] Munn, N.L., Fernald, D.L. and Fernal, P.S. (1969) Introduction to Psychology. Houghton Mifflin Co., Boston.

[6] Brown, S.P. (1996) A Meta-Analysis and Review of Organizational Research on Job Involvement. Psychological Bulletin, 120, 235-255. https://doi.org/10.1037/0033-2909.120.2.235

[7] Hsu, C.H.C., Cai, L.A. and Li, M. (2010) Expectation, Motivation, and Attitude: A Tourist Behavioral Model. Journal of Travel Research, 49, 282-296. https://doi.org/10.1177/0047287509349266

[8] Driver, B.L., Brown, P.J. and Peterson, G.L. (1977) Benefits of Leisure. Venture, State College.

[9] Crandall, R. (1980) Motivation for Leisure. Journal of Leisure Research, 12, 45-53. https://doi.org/10.1080/00222216.1980.11969418

[10] Beard, J.G. and Raghed, M.G. (1983) Measuring Leisure Motivation. Journal of Leisure Research, 15, 219-228. https://doi.org/10.1080/00222216.1983.11969557

[11] Manfredo, M.J., Driver, B.L. and Tarrant, M.A. (1996) Measuring Leisure Motivation: A Meta-Analysis of the Recreation Experience Preference Scales. Journal of Leisure Research, 28, 188-213. https://doi.org/10.1080/00222216.1996.11949770 
[12] Whiting, J.W., Larson, L.R., Green, G.T. and Kralowe, C. (2017) Outdoor Recreation Motivation and Site Preferences across Diverse Racial/Ethnic Groups: A Case Study of Georgia State Parks. Journal of Outdoor Recreation and Tourism, 18, 10-21. https://doi.org/10.1016/j.jort.2017.02.001

[13] Brooker, E., Joppe, M.M., Davidson, C.G. and Marles, K. (2012) Innovation within the Australian Outdoor Hospitality Parks Industry. International Journal of Contemporary Hospitality Management, 24, 682-700. https://doi.org/10.1108/09596111211237246

[14] Brooker, E. and Joppe, M.M. (2013) Trends in Camping and Outdoor Hospitality-An International Review. Journal of Outdoor Recreation and Tourism, 3, 1-6. https://doi.org/10.1016/j.jort.2013.04.005

[15] Brochado, A. and Pereira, C. (2017) Comfortable Experiences in Nature Accommodation: Perceived Service Quality in Glamping. Journal of Outdoor Recreation and Tourism, 17, 77-83. https://doi.org/10.1016/j.jort.2017.01.005

[16] Schmitt, B. (1999) Experiential Marketing. Journal of Marketing Management, 15, 53-67. https://doi.org/10.1362/026725799784870496

[17] Schmitt, B. (1999) Experiential Marketing: How to Get Customers to Sense, Feel, Think, Act, and Relate to Your Company and Brands. Free Press, New York.

[18] Skandalis, A., Byrom, J. and Banister, E. (2019) Experiential Marketing and the Changing Nature of Extraordinary Experiences in Post-Postmodern Consumer Culture. Journal of Business Research, 97, 43-50. https://doi.org/10.1016/j.jbusres.2018.12.056

[19] Garst, B., Williams, D. and Roggenbuck, J. (2010) Exploring Early Twenty-First Century Developed Forest Camping Experiences and Meanings. Leisure Sciences. An Interdisciplinary Journal, 32, 90-107. https://doi.org/10.1080/01490400903430905

[20] Schelbe, L., Deichen Hansen, M.E., France, V.L., Rony, M. and Twichell, K.E. (2019) Does Camp Make a Difference? Camp Counselors' Perceptions of How Camp Impacted Youth. Children and Youth Services Review, 93, 441-450. https://doi.org/10.1016/j.childyouth.2018.08.022

[21] Fort, M., Lundberg, N., Zabriskie, R., Eggett, D., Prater, M.A. and Barney, K. (2016) Adolescent Summer Camp Volunteers' Attitudes toward Peers with Disabilities. Leisure Sciences, 39, 277-294. https://doi.org/10.1080/01490400.2016.1171740

[22] Kotler, P. (1997) Marketing Management Analysis. Planning, Implementation, and Control. 9th Edition, Prentice-Hall, Upper Saddle River.

[23] Tian-Cole, S. and Cromption, J. (2003) A Conceptualization of the Relationships between Service Quality and Visitor Satisfaction, and Their Links to Destination Selection. Leisure Studies, 22, 65-80. https://doi.org/10.1080/02614360306572

[24] Oliver, R.L. (1981) Measurement and Evaluation of Satisfaction Processes in Retailing Setting. Journal of Retailing, 57, 25-48.

[25] Moore, R.L. and Driver, B. (2005) Introduction to Outdoor Recreation: Providing and Managing Natural Resource Based Opportunities. Journal of Park Recreation Administration, 25, 113-115.

[26] Manning, R.E. (1999) Studies in Outdoor Recreation: Search and Research for Satisfaction. Oregon State University Press, Corvallis, 25.

[27] Bultena, G.L. and Klessig, L.L. (1969) Satisfaction in Camping: A Conceptualization and Guide to Social Research. Journal of Leisure Research, 1, 348-354. https://doi.org/10.1080/00222216.1969.11969749 
[28] Graefe, A.R. and Burns, R.C. (2013) Testing a Mediation Model of Customer Service and Satisfaction in Outdoor Recreation. Journal of Outdoor Recreation \& Tourism, 3, 36-46. https://doi.org/10.1016/j.jort.2013.09.006

[29] Dann, G.M.S. (1981) Tourist Motivation an Appraisal. Annals of Tourism Research, 8, 187-219. https://doi.org/10.1016/0160-7383(81)90082-7

[30] Fluker, M.R. and Turner, L.W. (2000) Needs, Motivations, and Expectations of a Commercial Whitewater Rafting Experience. Journal of Travel Research, 38, 380-389. https://doi.org/10.1177/004728750003800406

[31] Battour, M.M., Battor, M.M. and Ismail, M. (2012) The Mediating Role of Tourist Satisfaction: A Study of Muslim Tourists in Malaysia. Journal of Travel \& Tourism Marketing, 29, 279-297. https://doi.org/10.1080/10548408.2012.666174

[32] Lee, T.H. and Hsu, F.Y. (2013) Examining How Attending Motivation and Satisfaction Affects the Loyalty for Attendees at Aboriginal Festivals. International Journal of Tourism Research, 15, 18-34. https://doi.org/10.1002/jtr.867

[33] Prebensen, N.K., Woo, E., Chen, J.S. and Uysal, M. (2013) Motivation and Involvement as Antecedents of the Perceived Value of the Destination Experience. Journal of Travel Research, 52, 253-264. https://doi.org/10.1177/0047287512461181

[34] Battour, M., Ismail, M.N., Battor, M. and Awais, M. (2017) Islamic Tourism: An Empirical Examination of Travel Motivation and Satisfaction in Malaysia. Current Issues in Tourism, 20, 50-67. https://doi.org/10.1080/13683500.2014.965665

[35] Medina, M.Q. and Chaparro, J.P. (2008) The Impact of the Human Element in the Information Systems Quality for Decision Making and User Satisfaction. Journal of Computer Information Systems, 48, 44-52.

[36] Pavlou, P.A. and Fygenson, M. (2006) Understanding and Predicting Electronic Commerce Adoption: An Extension of the Theory of Planned Behavior. MIS Quarterly, 30, 115-143. https://doi.org/10.2307/25148720 